\section{DIGITAL COMMONS \\ @ UNIVERSITY OF SOUTH FLORIDA}

\section{ABO: Interactive Journal for Women in the Arts, 1640-1830}

Volume 4

Issue 2 Volume 4.2 (Fall 2014)

Article 5

2014

\title{
Review of Marilyn Francus, Monstrous Motherhood: Eighteenth- Century Culture and the Ideology of Domesticity
}

Phyllis Ann Thompson

East Tennessee State University, THOMPSOP@mail.etsu.edu

Follow this and additional works at: https://digitalcommons.usf.edu/abo

Part of the Dramatic Literature, Criticism and Theory Commons, Educational Methods Commons, Feminist, Gender, and Sexuality Studies Commons, and the Literature in English, British Isles Commons

\section{Recommended Citation}

Thompson, Phyllis Ann (2014) "Review of Marilyn Francus, Monstrous Motherhood: Eighteenth-Century Culture and the Ideology of Domesticity," ABO: Interactive Journal for Women in the Arts, 1640-1830:

Vol.4: Iss.2, Article 5.

http://dx.doi.org/10.5038/2157-7129.4.2.5

Available at: https://digitalcommons.usf.edu/abo/vol4/iss2/5

This Reviews is brought to you for free and open access by Digital Commons @ University of South Florida. It has been accepted for inclusion in ABO: Interactive Journal for Women in the Arts, 1640-1830 by an authorized administrator of Digital Commons @ University of South Florida. For more information, please contact digitalcommons@usf.edu. 
Review of Marilyn Francus, Monstrous Motherhood: Eighteenth-Century Culture and the Ideology of Domesticity

\author{
Abstract \\ Review of Marilyn Francus. Monstrous Motherhood: Eighteenth-Century Culture and the Ideology of \\ Domesticity. Baltimore: The Johns Hopkins UP, 2012. Xi + 297pp. Index. ISBN 978-1-4214-0737-1. \\ Keywords \\ motherhood, infanticide, domesticity, maternal, stepmother \\ Creative Commons License \\ (c) $($ ) $\ominus$
}

This work is licensed under a Creative Commons Attribution-No Derivative Works 3.0 License. 
Marilyn Francus. Monstrous Motherhood: Eighteenth-Century Culture and the Ideology of Domesticity. Baltimore: The Johns Hopkins UP, 2012. Xi + 297pp. Index. ISBN 978-1-42140737-1.

Reviewed by Phyllis Thompson

Director of Women's Studies

East Tennessee State University

Marilyn Francus' Monstrous Motherhood fills a gap in eighteenth-century studies. Since the publication of Nancy Armstrong's Desire and Domestic Fiction: A Political History of the Novel (1987), scholars have viewed the idealized image of the domestic female as icon for standards of female behavior. While important studies, such as Mary Poovey's The Proper Lady and the Woman Writer (1984), Leonore Davidoff's and Catherine Hall's Family Fortunes: Men and Women of the English Middle Class, 1780-1850 (1987), and Michael McKeon's The Secret History of Domesticity: Public, Private, and the Division of Knowledge (2005), may date the rise of domestic ideology differently or contest the social construction of public and private spaces, they all agree domesticity and femininity became increasingly synonymous over the course of the eighteenth century. Francus' Monstrous Motherhood demonstrates that previous studies largely "limit the discussion of the domestic woman to the courting female" (7) in courtship novels, which promotes misleading generalizations about uniformity of experience and obscures the relevance of other subject positions to a discussion of domestic ideology. Francus argues that by reclaiming the "narratives of motherhood - of the mothers who ghost novels like Pamela, Emma, and Jane Eyre - [her] book acknowledges but looks beyond the still-dominant commonplaces regarding eighteenth-century domestic ideology" (7-8). Instead of employing domestic ideology as a lens to examine representations of mothers, Francus uses the representations themselves to examine the ideology. By doing so, she teases out long-held assumptions that have obstructed a full view of the eighteenth-century domestic female. She contends that literary, historical, and legal representations of motherhood not only reveal the limitations of a domestic ideology solely dependent on the single female but also reframe the discussion to highlight the diversity of experience and intricacy of identities that become apparent through her examination of four types of maternal performance-maternal dominance, infanticide, stepmotherhood, and maternal absence. Spanning the century from 1660-1820, Francus' study is an ambitious one. Her findings will change how we theorize domestic ideology in the field.

Maternal dominance can be observed in allegorical renderings of mothers and motherhood that were portrayed as dangerous, excessive, and unrestrained. Francus argues that these depictions lead, on the one hand, to male disgust of fertility and fear of sexuality and, on the other, to strategies of female containment that were deemed necessary to keep the monstrous mother in check. Francus presents Hester Thrale as a historical test case to examine the cultural expectation of the selfless mother and the societal tendency to pass judgment on mothers who strayed from the straight and narrow. As a bridge connecting the first two chapters, Francus demonstrates how Thrale becomes the real-life embodiment of Swift's and Pope's monstrous mothers, conceptualized allegorically as Criticism and Dulness. Francus' meticulous analysis shows how the narrative of Thrale's life underscores the complexities of motherhood, illustrating the tension that erupts from the burden of bearing the heavy physical and psychological responsibility of 
motherhood within a social framework that effaces and disempowers those who take on that responsibility. The irony Francus asserts is that while mothers needed strong wills, clear senses of judgment, and independent spirits to nurture and raise children, they were encouraged to adopt submissive spirits and selfless attitudes in relation to their children. The social expectation required self-sacrifice while the job necessitated a strong ego and self-reliance. As Francus' argument confirms, the practical details of mothering often challenged eighteenth-century constructions of the good mother or polite female behavior. The result was that mothers were expected to suppress their authority in the household in relation to their children and with respect to their desires, sexuality, and independence as women. Hester Thrale's life story is a case in point. In a chapter as poignant as it is academic, Francus illustrates that in "making the distinction between her obligations to herself and her obligations to her daughters, [Thrale] refused erasure by refusing to live only for (and through) her children. In doing so, Hester not only called into question the role of motherhood in a woman's life but highlighted the difficulties of navigating desire and sexuality as a woman and mother" (72).

Infanticide is depicted differently in literature and the law. Francus reads infanticide as a site of contention as literary depictions tend to focus on married women accused of murdering their children and legal narratives tend to focus on unmarried women concealing pregnancies. In literature, the infanticide is portrayed as public spectacle and the result as private catharsis; in the legal system, infanticide puts the emphasis on the private concealment while the punishment is public. The British infanticide statute, enacted in 1624, not only placed the burden of proof on the mother but also interpreted concealment of a pregnancy as guilt. As a result, during the Restoration, conviction rates were high. While there was a decrease in conviction rates by midcentury, probably due to better defense strategies, there was an increase in the demonization of infanticidal mothers and their crimes. Francus writes, "the increasing discrepancy between the laws specific to the crime of infanticide and the reality of its prosecution can be attributed to a displacement of monstrosity by the court, which clearly distinguished a 'good' infanticidal mother from an increasingly demonized 'bad' one" (100). Thus, docility was rewarded by the court and agency prosecuted. The docile mother who was contrite and submitted to authority was acquitted and returned to the working classes; her unwanted baby was hardly missed and her crime practically excused in order to return her to the work force. The disruptive, rebellious mother, on the other hand, "challenged established boundaries, exposing and undermining social assumptions regarding maternity, reputation, and female psychology" (101). The defiant infanticidal mother was portrayed as monstrous within and thus became a threat to the status quo. Francus shows that literary and legal narratives document Britain's tendency to erase infanticide as personal, social, and economic realities by either reinstalling the docile infanticidal mother back into society and thus saving her from both the scaffold and a life of crime, or by executing her insubordinate counterpart. Either way both infanticidal mothers and their stories were silenced.

By examining the ways literature and society have done more to obscure than reveal the stepmother's perspective, Francus' analysis demonstrates that the wicked stepmother is not just the evil twin of the good mother but a vehicle for challenging patriarchal assumptions, exploring the relationship of marriage and sex on parenting, and dismissing the dead mother. Unlike the polite and submissive good stepmother, the wicked stepmother behaves badly, demands selfgratification, and fails "to fulfill the domestic agenda" (148). By this, she exposes the problems 
in the patriarchy, but for this she is punished and becomes the scapegoat for author and reader. As Francus convincingly argues, "the narrative of the wicked stepmother flourishes precisely because she provides a vehicle for the judgment of mothers" (148). By drawing on biographical sources, Francus also reveals that the narratives of historical stepmothers often reinforce the wicked stepmother stereotype even in light of evidence to the contrary. Frances Burney's family history serves as a case in point as it not only marginalizes her stepmother Elizabeth Allen Burney, but also effectively edits her out of the family narrative. Furthermore, their family history presents a construction of stepmotherhood dependent on a narrative view constructed not on fact but conceived by the Burney children, indicating the children's role in family relations and in the silencing of their stepmother.

Francus concludes her study with "the rise of the spectral mother" (170), who neither fully imitates nor criticizes domesticity. She provides an alternative to the ideal mother who embodies domesticity but lacks voice and to the monstrous mother who disrupts domesticity through excess. Spectral mothers neither advocate for nor disparage domesticity but question the assumptions on which such a view of motherhood is constructed. Francus treats three manifestations of spectral maternity-absence, surveillance, and death. Her analysis of, for instance, the absent mother in Burney's Camilla, the surveilling mother in Defoe's Roxana, and the dead mother in Burney's Evelina demonstrates that motherhood is "an ongoing site of contest, and the strategies to domesticate mothers never quite succeeded . . ." (202).

If Monstrous Motherhood has an imperfection, it would be in the slight shifts of style and theoretical approach that result when one reformulates a selection of previously published, discrete articles into a book. However, the nearly twenty years of research that culminated in those articles and this monograph laid the groundwork for its author to reweave the complicated fabric of women's lives into a narrative tapestry as convincing as it is engaging. Marilyn Francus' Monstrous Motherhood is a meticulously researched and comprehensive study that will change the way our field discusses domesticity and is essential reading for scholars of literature, women's studies, and cultural studies. 